\title{
The Growth of Chalcedony (Nanocrystalline Silica) in Electric Organs from Living Marine Fish
}

\author{
María Prado Figueroa \\ Instituto de Investigaciones Bioquímicas (INIBIBB) \\ CONICET, Universidad Nacional del Sur (UNS) \\ Departamento de Biología, Bioquímica y Farmacia \\ Bahía Blanca, \\ Argentina
}

\section{Introduction}

The Rajidae Family are weakly electric fish (Fessard, 1958). Psammobatis extenta (Rajidae Family) is a South American electric fish. Electric organs of the electric fish have constituted the choice system for studying the biochemistry, morphology, physiology and cell biology of the nervous cholinergic system (Barrantes et al., 1983; Changeux, 1981; 2010; Fox et al., 1990; Prado Figueroa et al., 1995; Wittaker, 1977). Electric organs derive embryologically from myoblasts and are constituted by cells called electrocytes.

The electric organs (EO) of Psammobatis extenta produce weak electrical discharges to the surrounding environment. Electrocytes have evolved and differential independently, losing the contractile ability. In previous works we employed a microanalysis (EDS-SEM) and documented the presence of aluminium and silicon in significant concentrations. Zinc, oxygen and cupper were also localized.

Silicon (Si) is an essential nutrient for animal biology (Carlisle 1982). It has been shown that silicon is required for bone, cartilage and connective tissue formation (Bissé et al. 2005). Silicon may function as a biological cross-linking agent and may contribute to the architecture and resilience of connective tissue (Schwarz 1973). Aluminium (Al) and Si accumulations have been detected in electric organs by a combination of scanning electron microscopy and X-ray spectrometry (EDS-SEM) (Prado Figueroa et al., 2008). Al and Si have been also detected in the human cerebral cortex from elderly people by using EDS/SEM (Perl and Brody 1980, Candy et al. 1985). These inorganic elements are related to pathological changes in the human brain (Candy et al. 1985, Tokutake et al. 1995).

Biomineralization is the process by which living organisms produce minerals, often to harden or stiffen existing tissues. Chalcedony is a microcrystalline fibrous form of silica $\left(\mathrm{SiO}_{2}\right)$ and it is the product of biomineralization by silica (Erhlich et al., 2010). We have identified chalcedony in living fish electric organs by using a standard polarized light microscope (Prado Figueroa et al., 2008). In plane-polarized light, chalcedony is rounded in 
shape, 12-15 micron in size, translucent, with a low refraction index. The crossed-polarizer image shows first order birefringence colour (grey-white) and radial extinction.

In this chapter, we document the visualization and identification of chalcedony crystals in electric organs, by using a Leica TCS - SP2 Laser Scanning Confocal Microscope (LSCM). Three ion lasers were used i.e.: argon with emission band in $458 \mathrm{~nm}$ (cyan), $476 \mathrm{~nm}$ (bluegreen), $488 \mathrm{~nm}$ (green) and $514 \mathrm{~nm}$ (yellow); He/Ne in $543 \mathrm{~nm}$ with emission band in red, and $\mathrm{He} / \mathrm{Ne}$ with emission band in $633 \mathrm{~nm}$ (blue). The autofluorescent character of chalcedony (a mineral) allowed us to obtain images of the crystals together with a topographic study. Chalcedony consists of nanoscale intergrowths of silica polymorphs: quartz and moganite (Heaney \& Post, 1992). These silica polymorphs, with their two different nanocrystal structures, are described in the present chapter. Quartz and moganite are both identified in three-dimensional (3-D) images using a LSCM and Leica software. 3-D images were generated as "surface": the blank spaces between the pixels are filled. 3-D images were also generated as "wireframe": all pixels are linked with lines, while the blank spaces remain free. Many images generated by differential interference contrast (DIC) are also shown in this chapter.

\section{Biomineralization by silica in electric fish}

Biomineralization by silica is a complicated process observed in living organisms. Of the intriguing topics that are receiving renewed attention, the study of biomineral formation based on organic templates is one of the most fascinating topics today (Ehrlich, 2010; Ehrlich et al., 2010). Biosilicification is an evolutionarily old and widespread type of biomineralization both in unicellular and multicellular organisms, including sponges, diatoms, radiolarians, choanoflagellates, and higher plants (Schroeder et al., 2008).

We have studied Psammobatis extenta electric organs from the Rajidae family, a group of elasmobranch electric fish. Electric organs are structures specialized in the production of electric discharges (Fessard, 1958). Their major cell components, called electrocytes, are highly polarized. We could detect biomineralization by microcrystalline silica in P. extenta electric organs (Prado Figueroa et al., 2008).

\subsection{Psammobatis extenta: A Rajidae family fish}

Adult female and male P. extenta were collected from the Bahía Blanca Estuary $\left(38^{\circ} 40^{\prime} \mathrm{S}\right.$ and $39^{\circ} 30^{\prime} \mathrm{S}, 62^{\circ} 16^{\prime} \mathrm{W}$ and $63^{\circ} 26^{\prime} \mathrm{W}$ ) in the Buenos Aires Province, Argentina and transported to the laboratory in sealed polyethylene bags containing oxygen-saturated seawater.

The fish were anesthetized by immersion in ice cold seawater for $10 \mathrm{~min}$ and then killed by pithing. Immediately after dissection of the ray, the electric tissue was frozen in liquid nitrogen at $-198^{\circ} \mathrm{C}$.

Electrocytes from $P$. extenta are cup-shaped cells, multinucleated and polarized. They have an anterior, concave, innervated face and a posterior, convex, non-innervated face, that shows a very large system of caveolae (Prado Figueroa et al., 1995). These cup-shaped electrocytes are plesiomorphic, phylogenies based on morphological data (Jacob et al., 1994). Neuronal cell death and synaptic terminal degeneration have been noted in the adult electric organs of fish from the Rajidae family (Fox et al., 1990 and our observations). 
Understanding cellular and molecular mechanisms participating in neurodegenerative process is thus an important field of research.

\subsection{Silicon in electric organs}

Silicon is an essential element for animals (Carlisle, 1982). Silicon may function as a biological cross-linking agent and may contribute to the architecture and resilience of connective tissue (Schwarz, 1973). It has also been documented that silicon is present as a silanolate, i.e., an ester-like derivative of silicic acid and plays a role in the structural organization of glycosaminoglycans and polyuronides (Schwarz, 1973).

We could observe aluminium and silicon in the cytoplasmic extracts of $P$. extenta electric tissue (Prado Figueroa et al., 2008) using a combination of scanning electron microscopy and X-ray spectrometry (EDS/SEM) (see Fig. 1). The result of this microanalysis is an energydispersive spectrum in which the peaks are localized at energy lines characteristic for each element

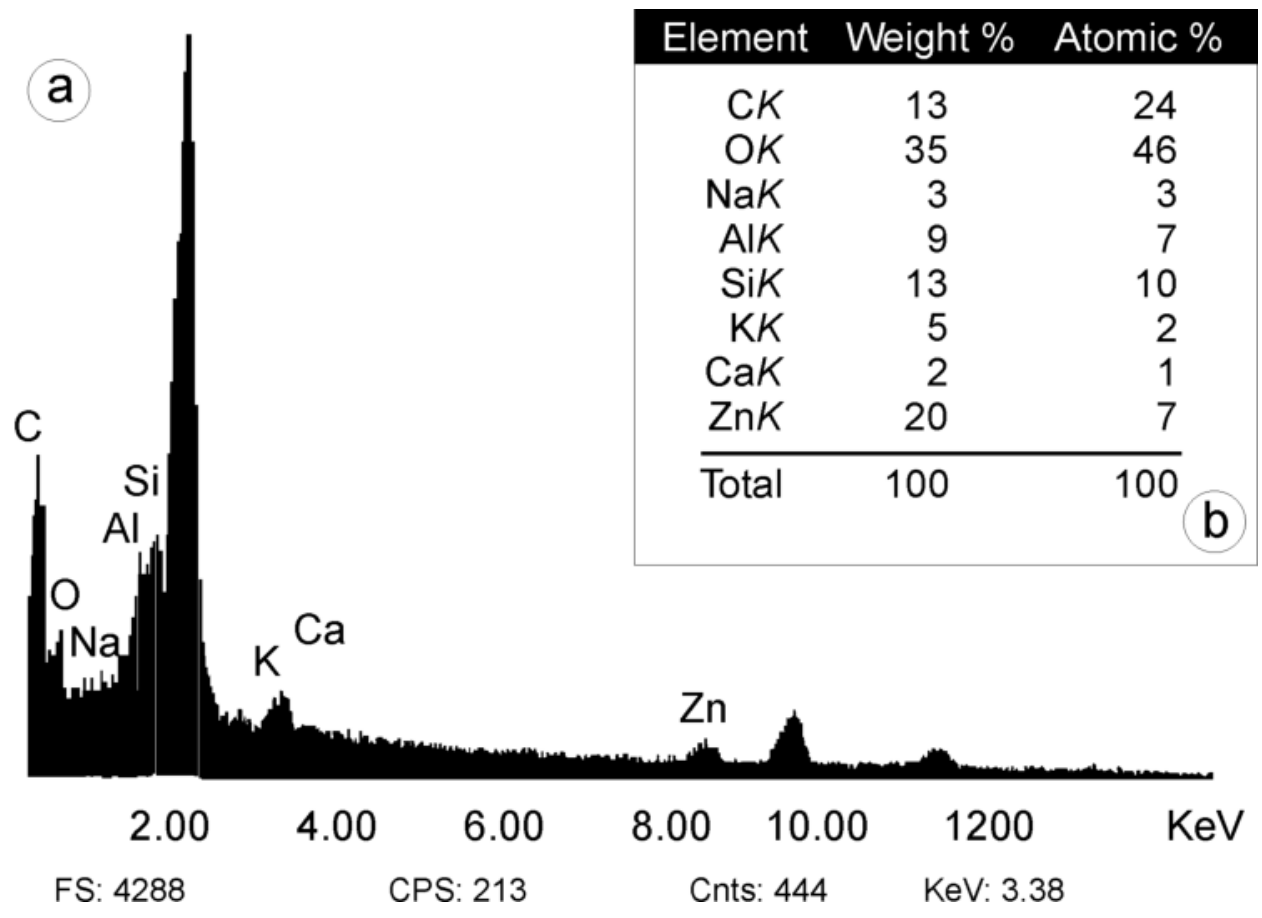

Fig. 1. Electric organ cytoplasmic extracts from Psammobatis extenta on lyophilised paper and metalized with gold were microanalyzed by using EDS/SEM. This energy dispersive spectrum (a) shows high peaks localized at energy lines characteristic for oxygen, silicon and aluminium. Sodium, potassium, calcium and zinc are also observed. Weight and atomic percents for these elements are indicated next to the spectrum (b). 
An electric organ cytoplasmic extract $(50 \mu \mathrm{l})$ on lyophilised paper (Labconco Corp., USA) was fixed in $2.5 \%$ glutaraldehyde in a $0.05 \mathrm{M}$ sodium phosphate buffer ( $\mathrm{pH} 7.2)$ for $60 \mathrm{~min}$ at $4{ }^{\circ} \mathrm{C}$. Samples were washed with buffer and bi-distilled water for $2 \mathrm{~h}$, then, dehydrated. (For more detail of this method, see Prado Figueroa et al., 2008).

This method (EDS/SEM) has also been used for studying photosensitizers in electric tissue (Prado Figueroa \& Santiago, 2004).

\subsection{Microcrystalline silica in electric organs}

Based on the evidence of aluminum and silicium accumulation in P. extenta, we documented the presence of silica minerals in $P$. extenta electric tissue by means of mineralogical techniques (Prado Figueroa et al., 2008). It was thought that these compounds could form minerals (i.e., solid inorganic substances with a defined chemical composition and determined crystallography).

Fractionation of electric tissue homogenates by differential centrifugation was carried out as described for other tissues (Beaufay and Amar-Costesec, 1976; Amar-Costesec et al., 1985)

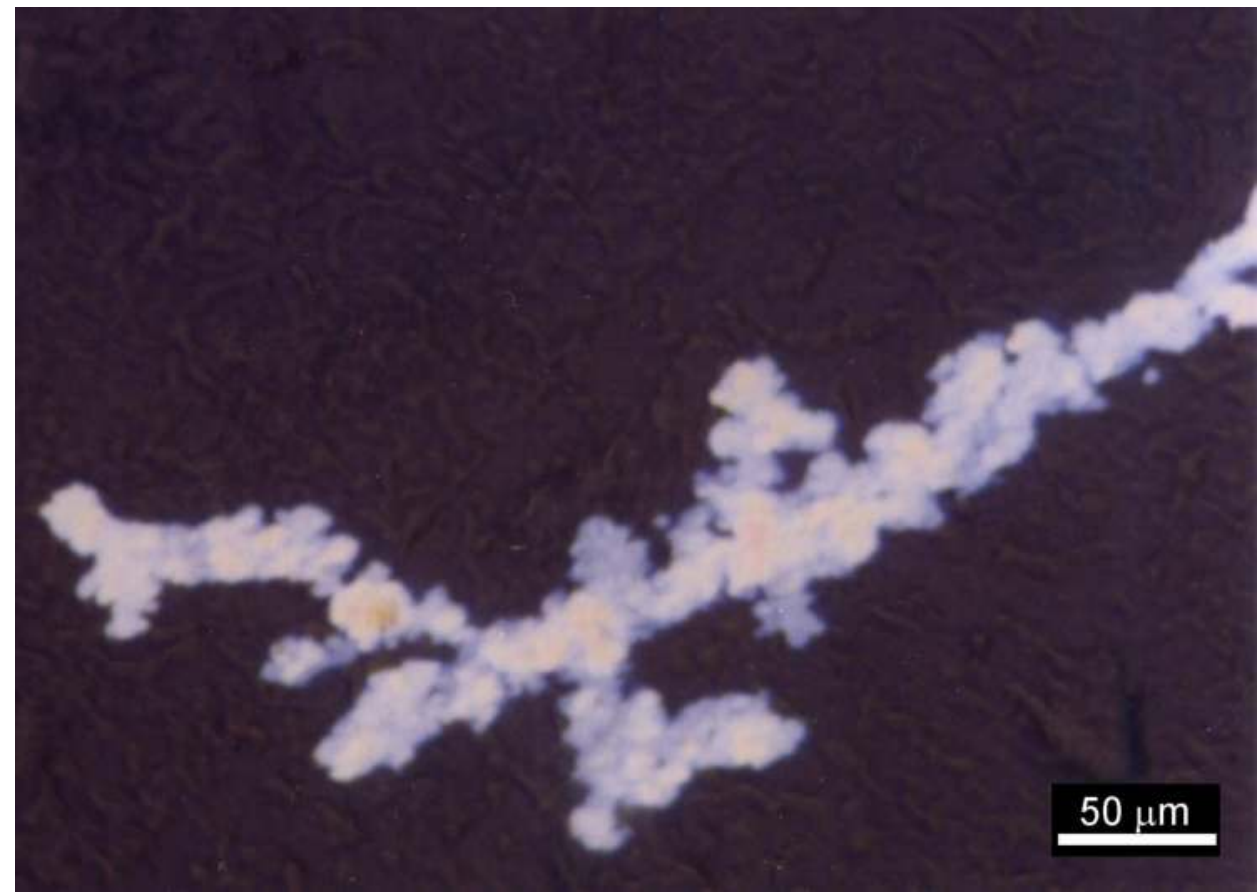

Fig. 2. Photomicrograph of a cytoplasmic extract of the electric organ from P. extenta in crossed-polarizers, by using a standard polarized light microscope.

The crossed-polarizer image of a cytoplasmic extract shows $\mathrm{SiO}_{2}$ replacements in grey and white arrangements, with undulatory extinction. 
using isotonic $3 \mathrm{mM}$ imidazole-HCl-buffered $0.25 \mathrm{M}$ sucrose ( $\mathrm{pH}$ 7.4). The following fractions were obtained: cytoplasmic extract (E), nuclear fraction (N), large granules (ML), microsomes $(\mathrm{P})$ and supernatant $(\mathrm{S})$. Drops of the fractions were collected on glass slides, dried and mounted in PBS/glycerol. These fractions were inspected using a Leica polarized light microscope (DMLP). This microscope has a polarizer and a switchable analyzer. In mineralogical microscopy, when the light enters an anisotropic mineral, one which transmits light at different rates in different orientations, it is decomposed in two rays, oscillating in two orthogonal planes. This phenomenon is known as birefringence and allows for the identification of each mineral. In this microscope, with a circular graduated stage capable of a $360^{\circ}$ rotation, minerals in different positions display their optical properties, such as birefringence colour and extinction position, with crossed polarizers.

All electric organ fractions in crossed-polarizers show $\mathrm{SiO}_{2}$ replacements in grey and white arrangement, with undulatory extinction. The crossed-polarizer image of a cytoplasmic extract shows $\mathrm{SiO}_{2}$ replacements in grey and white arrangements (chalcedony), Fig. 2.

Electric organs without any treatment were also used for X-ray diffraction analysis. Different peaks were obtained from diffractometric analysis; specifically peaks belonged to a quartz (low quartz; Moore and Reynolds, 1997). (See: Prado Figueroa et al., 2008).

\section{Autofluorescent crystalline silica detected by using a LSCM}

Autofluorescence characteristics of minerals have been described by Henkel (1989). In this chapter, we document the visualization and identification of chalcedony crystals in electric organs, by using a Leica TCS - SP2 Laser Scanning Confocal Microscope (LSCM). This microscope has three ion lasers i.e.: argon with emission band in $458 \mathrm{~nm}$ (cyan), $476 \mathrm{~nm}$ (blue-green), $488 \mathrm{~nm}$ (green) and $514 \mathrm{~nm}$ (yellow); He/Ne with emission band in $543 \mathrm{~nm}$ (red) and $\mathrm{He} / \mathrm{Ne}$ with emission band in $633 \mathrm{~nm}$ (blue). Since chalcedony is characteristically an autofluorescent mineral, we were allowed to obtain images of crystals.

\subsection{Autofluorescent microcrystalline silica (chalcedony)}

Adult female and male P. extenta were collected from Bahía Blanca Estuary in Buenos Aires Province, Argentina. Fractionation of electric tissue homogenates by differential centrifugation was carried out as described in Section 2.1.

Fractions (nuclear fraction " $\mathrm{N}$ "; microsomes " $\mathrm{P}$ " and supernatant " $\mathrm{S}$ ") were used and observed with a LSCM. A nuclear fraction shows many autofluorescent crystals and also little electrocytes, Fig. 3. Electrocytes from the electric organ of the Patagonian ray Psammobatis extenta are very unusual cells: semicircular in shape, multinucleated and highly polarized. Their anterior face is concave and innervated by numerous nerve-endings.

Fig. 3 shows an unbroken electrocyte with many autofluorescent crystals, these were observed with an argon ion laser with emission band at $488 \mathrm{~nm}$ (green). This image was merged with (DIC).

Normally, the microsomal fraction contains membranes from the synaptic region. The microsomal fraction has many autofluorescent crystals. A crystal of chalcedony from the microsomal fraction, its dimensions and autofluorescent intensity (I, arbitrary units) are 


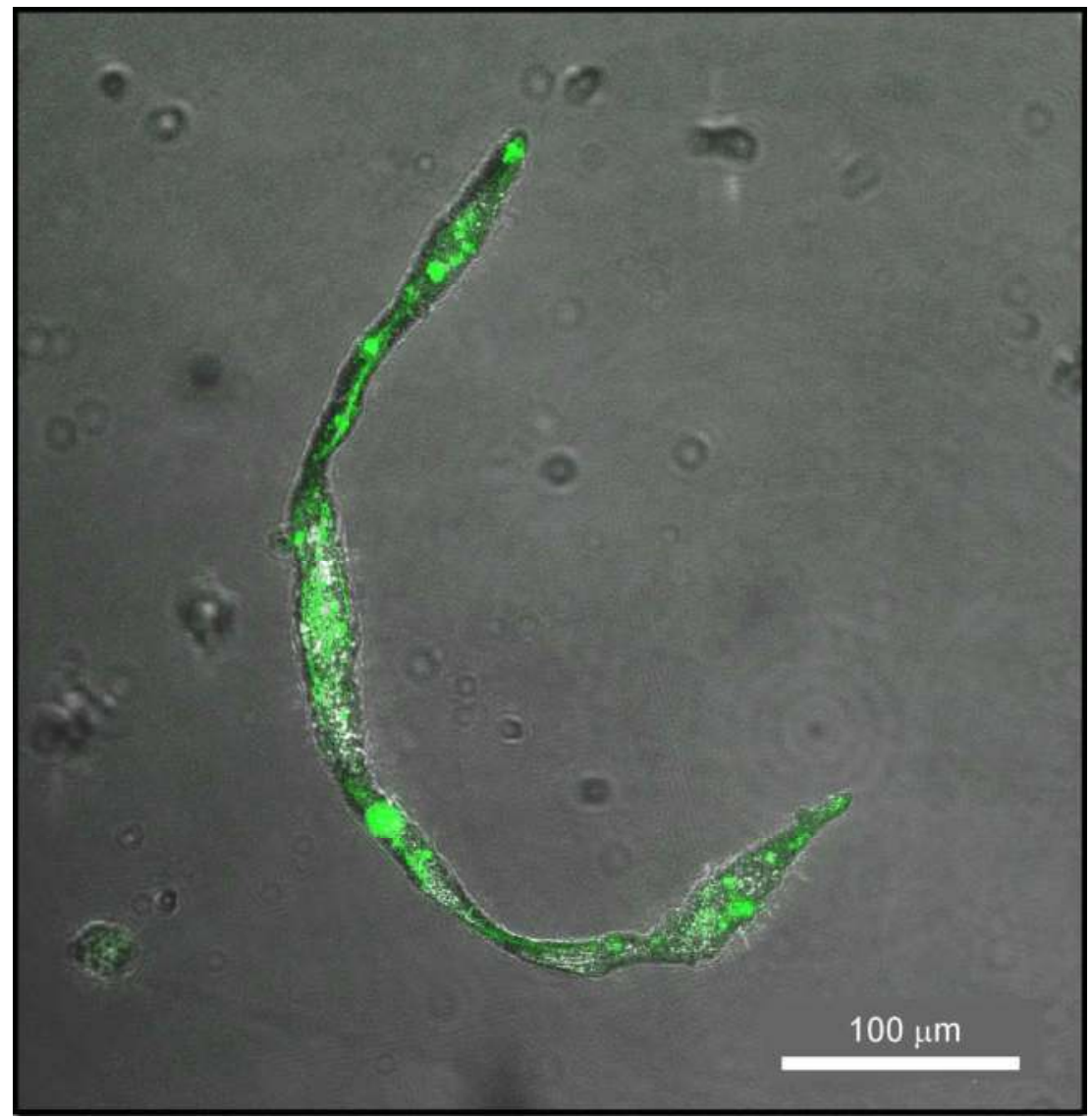

Fig. 3. Photomicrograph of a nuclear fraction of the electric organ from P. extenta in LSCM. This fraction shows a little electrocyte, which is unbroken. Many autofluorescent crystals were observed in the electrocyte with an Ar ion laser with emission band at $488 \mathrm{~nm}$ (green). This image was merged with DIC.

shown in Fig. 4. This image was obtained with an argon ion laser with emission band at 488 $\mathrm{nm}$ (green). This crystal is about 20 micron.

The crystal dimension and autofluorescent intensity (I) are shown in this image. This crystal was observed by using an argon ion laser with emission band at $488 \mathrm{~nm}$ (green).

Images of a chalcedony crystal from the microsomal fraction in LSCM are shown in Fig. 5.

Crystals from this fraction are rhombohedral in shape and they are in large quantities. This crystal is about 20 micron. The chalcedony crystal has autofluorescence with different ion lasers and is about 20 micron. A He/Ne ion laser with emission band in $543 \mathrm{~nm}$ (red), a $\mathrm{He} / \mathrm{Ne}$ ion laser with emission band in $633 \mathrm{~nm}$ (blue) and an Ar ion laser with emission bands in $458 \mathrm{~nm}$ (cyan), and $514 \mathrm{~nm}$ (yellow) were used. An image DIC of the crystal is shown (top, right side) and also all the images merged (botton, right side). 


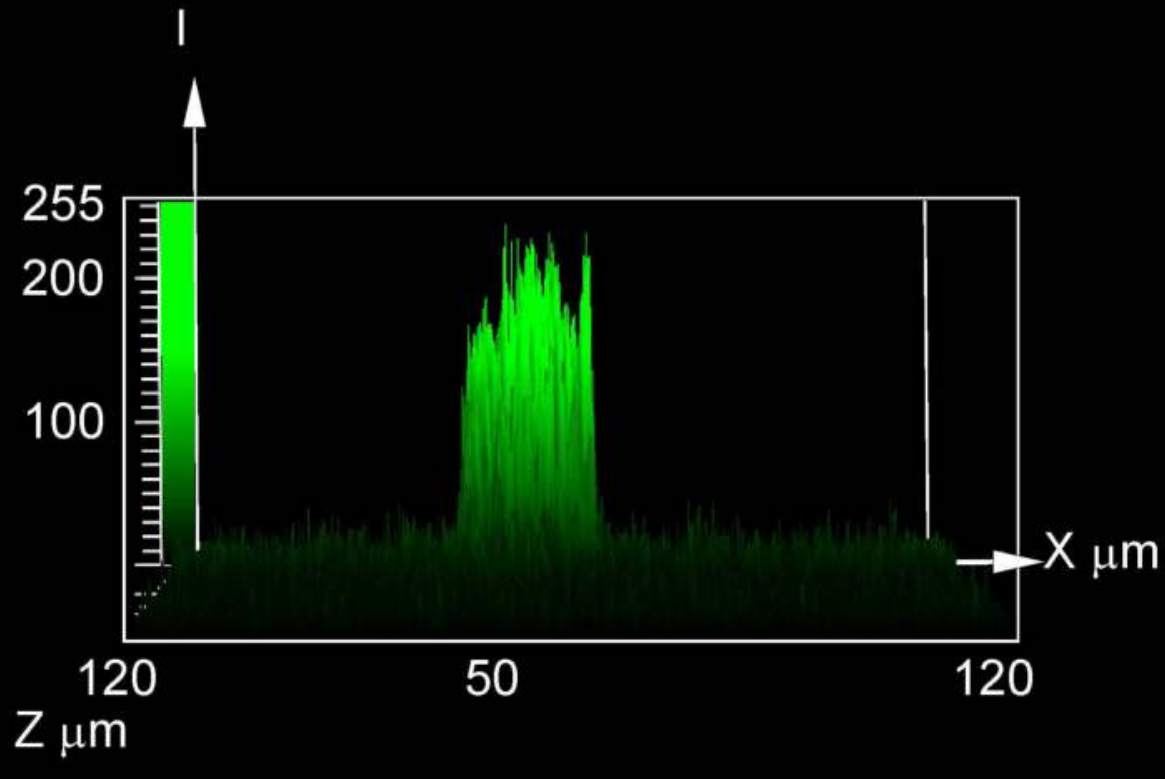

Fig. 4. An autofluorescent crystal of chalcedony from the microsomal fraction in LSCM.

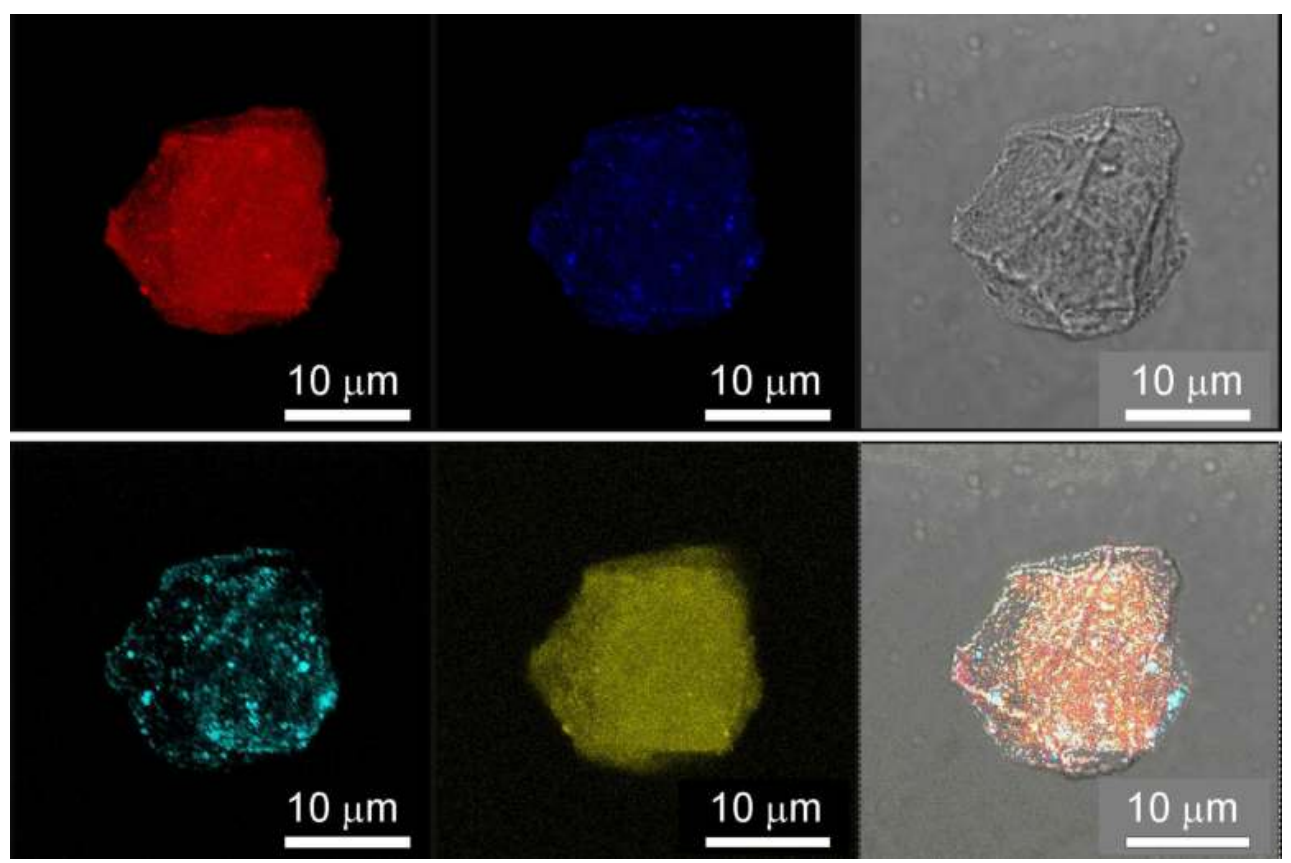

Fig. 5. Images of a chalcedony crystal from the microsomal fraction in LSCM. 
The chalcedony crystal has autofluorescence with different ion lasers: a He/ $\mathrm{Ne}$ ion laser with emission band in $543 \mathrm{~nm}$ (red); a He/Ne ion laser with emission band in $633 \mathrm{~nm}$ (blue); an Ar ion laser with emission bands in $458 \mathrm{~nm}$ (cyan), and $514 \mathrm{~nm}$ (yellow) were used. An image DIC of the crystal is shown and also all the images merged (right side, top and botton). This crystal is about $20 \mu \mathrm{m}$ in size.

An image of a chalcedony crystal from the supernatant fraction in LSCM is shown in Fig. 6, it was observed by using an argon ion laser with emission band at $488 \mathrm{~nm}$ (green). The chalcedony crystal has autofluorescence with different ion lasers and is about 10 micron in size. The supernatant fraction has many crystals.

\subsection{Autofluorescent nanocrystalline silica (silica polymorphs)}

Chalcedony is a microcrystalline fibrous form of silica which actually consists of nanoscale intergrowths of quartz and the optically length-slow fibrous silica polymorph moganite (Conrad et al., 2007; Deer et al., 1966; Heaney \& Post, 1992; Heaney, 1993; Heaney et al., 1994, 2007). Quartz and moganite are both silica minerals, but they differ in that quartz has a trigonal crystal structure $\left(\alpha, \beta, \gamma\right.$ different to $\left.90^{\circ}\right)$, whilst moganite has a monoclinic crystal structure ( $\alpha$ different to $90^{\circ}$ and $\beta, \gamma=90^{\circ}$ ). An image of silica polymorphs were obtained by using a LSCM with different emission bands, Fig. 7. This Fig. 7 shows a crystal of chalcedony from the microsomal fraction using an argon ion laser with emission bands in $458 \mathrm{~nm}$ (cyan) and 514 (yellow) merged and contrasted with DIC.

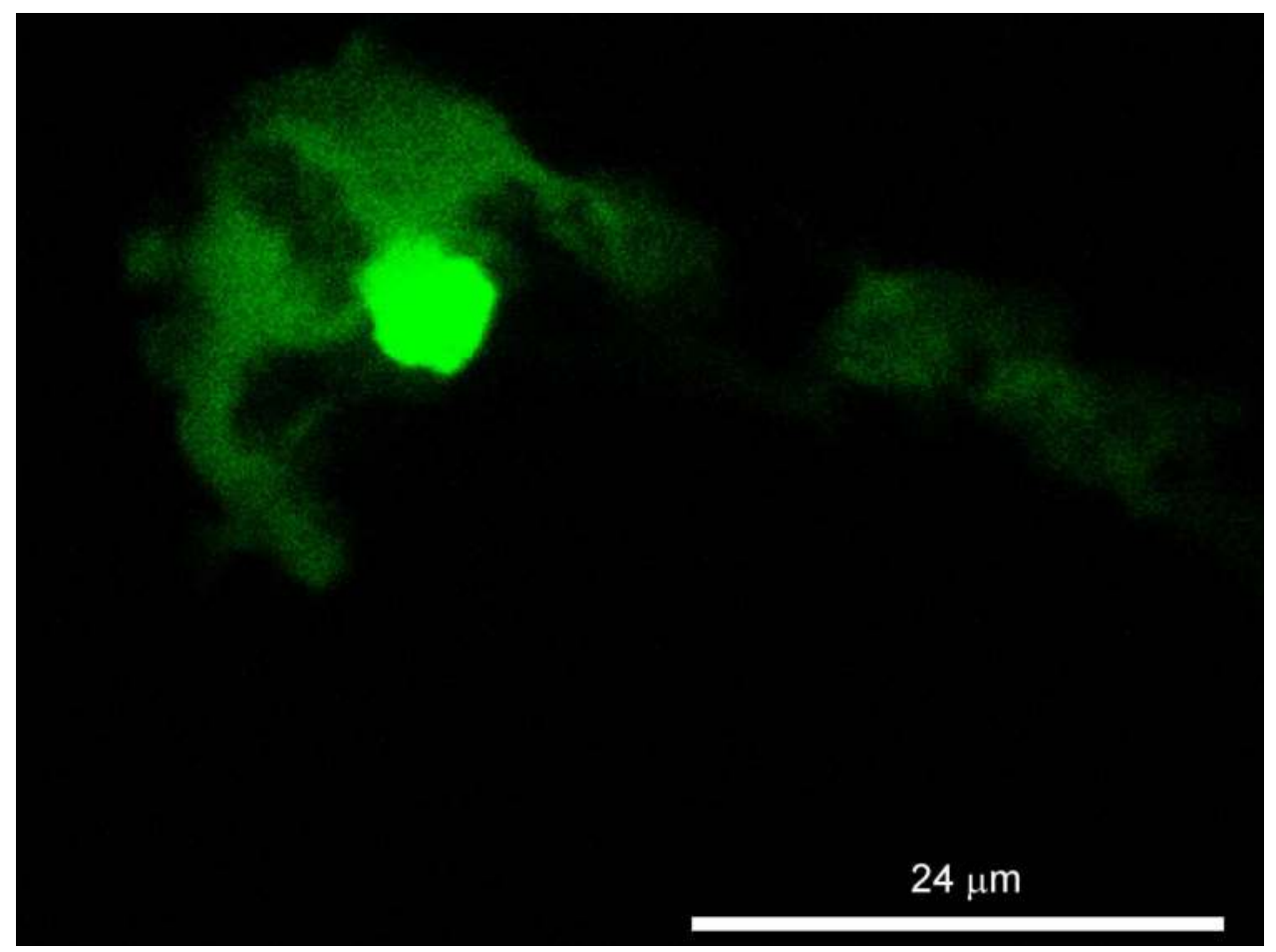

Fig. 6. A crystal of chalcedony from a supernatant fraction in LSCM. 
This chalcedony crystal was observed by using an argon ion laser with emission band at 488 $\mathrm{nm}$ (green). This crystal is about $10 \mu \mathrm{m}$. This fraction has many little autofluorescent crystals.

The same crystal of chalcedony (from Fig. 7) is shown in 3D images, Fig. 8. An argon ion

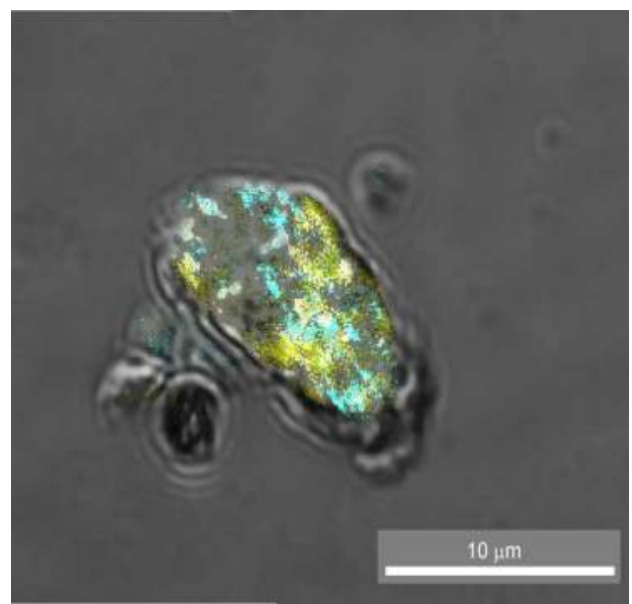

Fig. 7. A crystal of chalcedony from the microsomal fraction in LSCM. An argon ion laser was used, with emission bands in $458 \mathrm{~nm}$ (cyan) and $514 \mathrm{~nm}$ (yellow). Emissions were merged and contrasted with DIC.
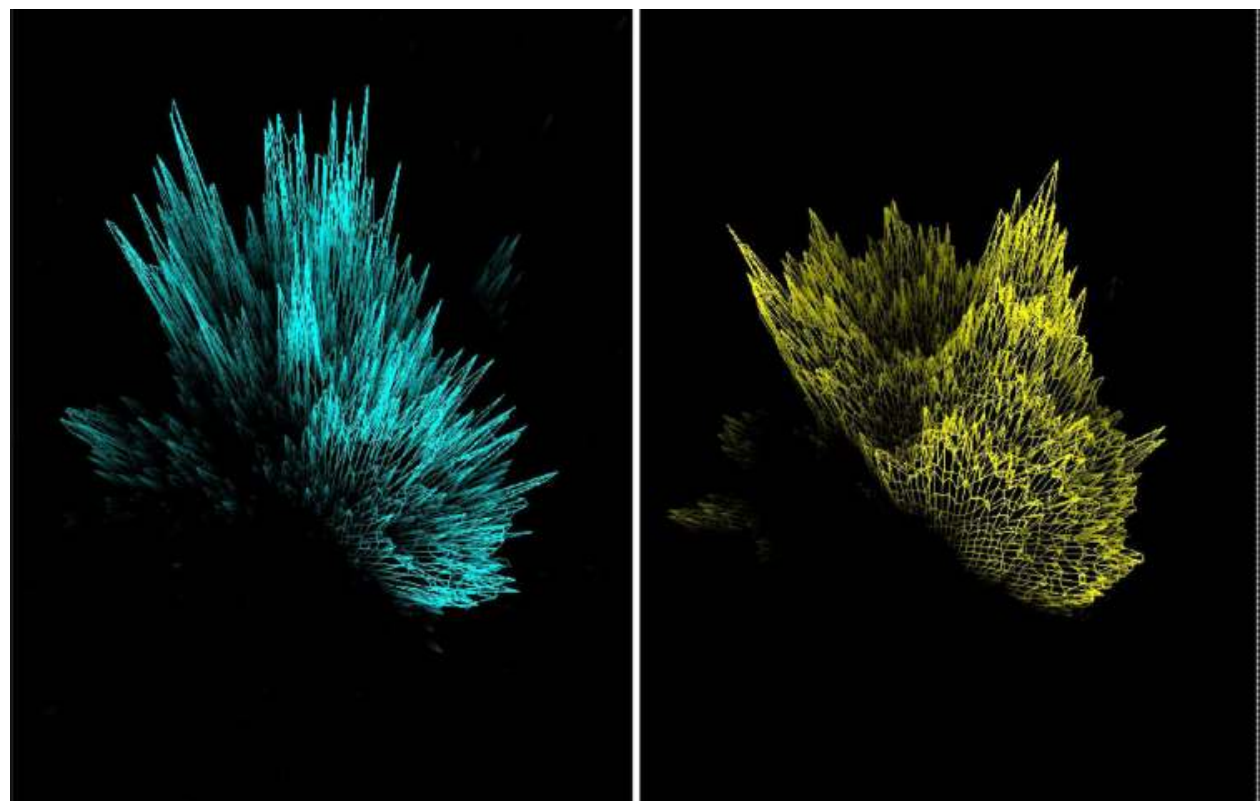

Fig. 8. 3-D images of the silica polymorphs from the microsomal fraction in LSCM . 
These images were obtained of the same crystal from Fig. 7. Cyan colour nanocrystals are acicular (pinacoid) in shape and nanocrystals in yellow are trapezohedral in shape.

laser was used with emission band in $458 \mathrm{~nm}$ (cyan) and $514 \mathrm{~nm}$ (yellow). Both nanocrystals are very different. Nanocrystals in cyan colour are acicular in shape. Nanocrystals in yellow are trapezohedral in shape. Quartz and moganite were detected by using ion lasers with different emission bands.
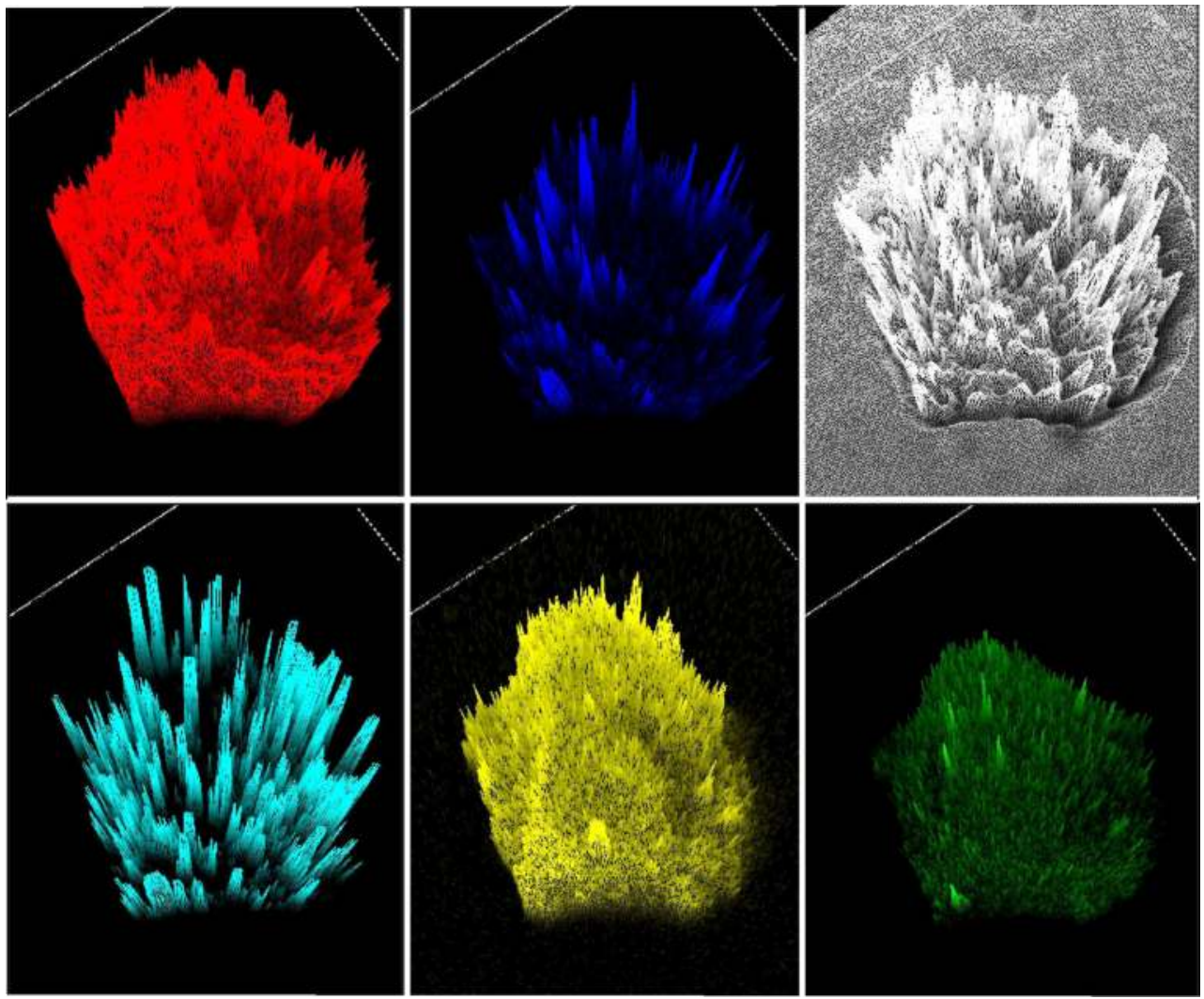

Fig. 9. 3D images of silica polymorphs nanocrystals from the microsomal fraction in LSCM.

The chalcedony crystal has autofluorescence with different ion lasers: a He/ $\mathrm{Ne}$ ion laser with emission band in $543 \mathrm{~nm}$ (red); a He/Ne ion laser with emission band in $633 \mathrm{~nm}$ (blue); 
an Ar ion laser with emission bands in $458 \mathrm{~nm}$ (cyan), $514 \mathrm{~nm}$ (yellow) and $488 \mathrm{~nm}$ (green). A DIC image of the crystal is shown (Top, right). This crystal is about $20 \mu \mathrm{m}$ in size.

Moganite nanocrystals are pinacoid (acicular) in shape and about 1 micron in size. Quartz nanocrystals are trapezohedral in shape, about 2 or 3 micron in size, and they are present in large quantities in chalcedony crystal.

3D images of nanocrystals from the microsomal fraction, shows silica polymorphs, Fig. 9.

The chalcedony crystal has autofluorescence with different ion lasers: a He/ $\mathrm{Ne}$ ion laser with emission band in $543 \mathrm{~nm}$ (red); a He/ Ne ion laser with emission band in $476 \mathrm{~nm}$ (blue); an argon ion laser with emission bands in $458 \mathrm{~nm}$ (cyan), $514 \mathrm{~nm}$ (yellow) and $488 \mathrm{~nm}$ (green). A DIC image of the crystal is shown (Fig. 9, top, right). This chalcedony crystal is about 20 micron in size and shows very different autofluorescent images. May be, this crystal image shows different degree of crystallization. This mineralization of the electrocytes implies the death of the cell and the nerves, revealing that these conditions of $\mathrm{pH}$ and Eh are necessary for this process to occur.

\section{Conclusion}

The origin of chalcedony (SiO2) has been widely discussed in the literature. Biomineralization by silica can occur under a wide variety of circumstances (Heaney, 1993; Fernández López, 2000; Nash \& Hopkinson, 2004). A slight oversaturation of silicon is necessary for allowing chalcedony formation from the solution.

A crystal is a solid material whose constituent atoms, molecules, or ions are arranged in an orderly repeating pattern extending in all three spatial dimensions (Hahn, 2002). Crystal habit depends on two main factors: the inner, crystalline structure determines the faces the crystal can present; growth conditions, however, determine the relative size of each face, and hence also the overall shape (Rasmuson, 2009).

The conditions at which silica formation occur is at a $\mathrm{pH} 7$ or near a $\mathrm{pH}$ of 8 and an Eh (oxidation potentials) of 0.0 to -0.2 (Fig. 10; Krumbein \& Garrels, 1952). It was documented oxidative stress in electric organs from Rajidae family fish (Prado Figueroa, 2005). In such oxidative conditions, the presence of iron could contributed to silica formation.

Crystal growth is a major stage in the crystallization process, and consists in the addition of new atoms, ions, or polymer. Details of the early stages of chalcedony genesis are not fully understood but could involve either the direct precipitation of amorphous silica from a hydrous fluid, which then evolves into chalcedony, or the direct growth of crystalline chalcedony (Moxon \& Carpenter, 2009).

The proportion of moganite decreases with age (Moxon, 2004; Moxon \& Carpenter, 2009). There is a correlation of crystallite growth with moganite content. The recrystallization of moganite to alfa-quartz clearly occurs at the same time as crystallite growth. Water has an important role: In the absence of water vapour, crystallite growth and transformation of moganite to quartz ceases (Moxon \& Carpenter, 2009). Moganite is abundant in arid environment, this is probably due to the lack of water available to support the dissolution of moganite and the simultaneous precipitation of quartz (Bustillo, 1992). 
The change in composition of internal water is proposed as a method for approximate dating of agates (a variety of chalcedony) (Moxon, 2004). It has been demonstrated in geological environments that less stable silica polymorphs appear to have transformed over time to chalcedony and microquartz (Nash \& Hopkinson, 2004).
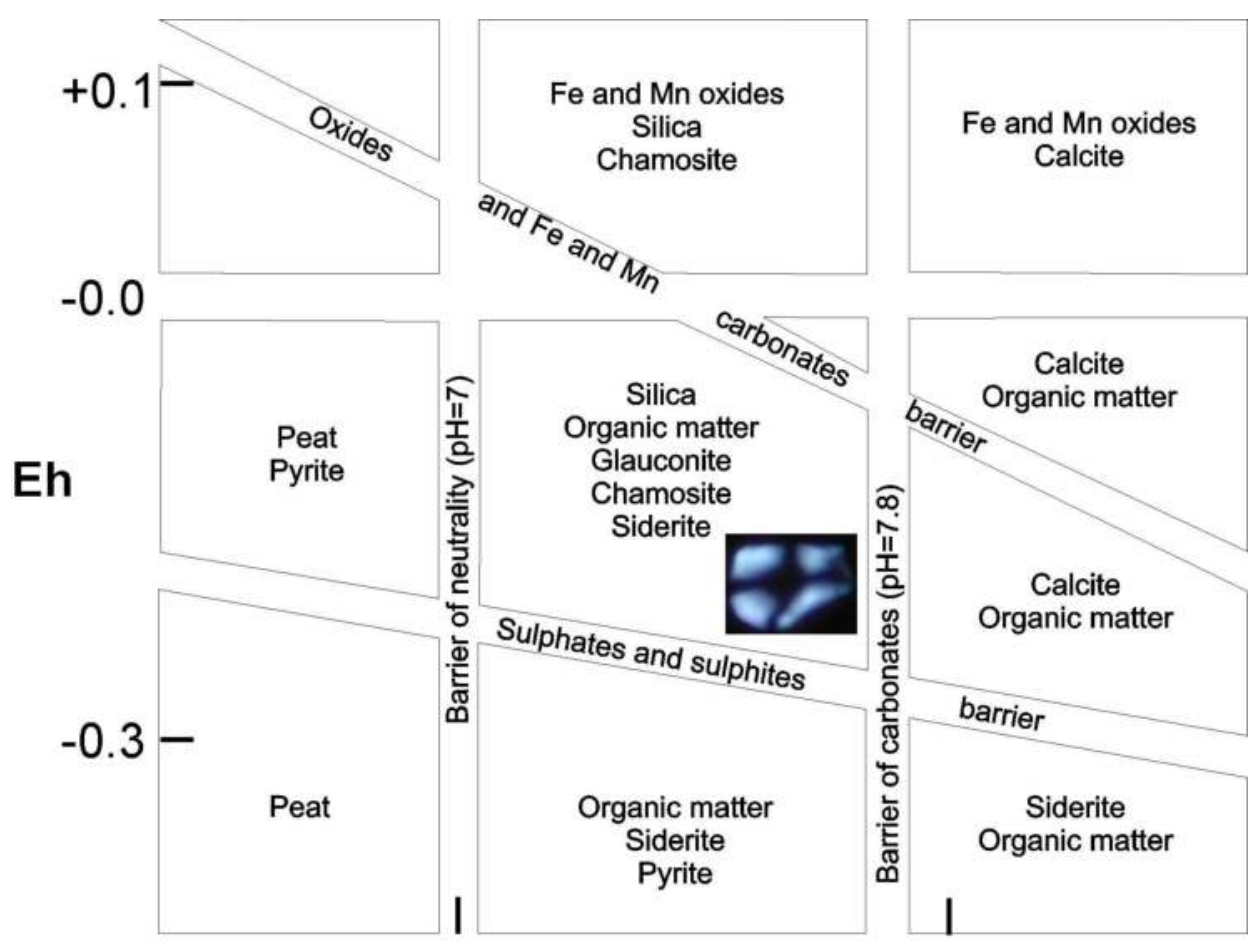

7

8

\section{$\mathrm{pH}$}

Fig. 10. Chalcedony formation. Krumbein, W.C., Garrels, R.M., (1952). 
It is possible to identify the silica polymorph components of chalcedony: quartz and moganite in 3-D images of nanocrystals, by using a Laser Scanning Confocal Microscope and Leica software, see Fig. 7. These quartz and moganite nanocrystals can be differentiated by using an argon ion laser with two emission bands: $514 \mathrm{~nm}$ (yellow emission) and $458 \mathrm{~nm}$ (cyan emission). These are shown at the Figs. 7 to 9. These figures perhaps show the growth of chalcedony in the electric organ from marine fish.

Quartz is estimated to occupy circa $12 \%$ of the earth's crust, so it is not surprising that research into its diverse applications has been of major interest for over 100 years. Important uses are made of quartz minerals that range from piezoelectric devices to the literal downto earth quartz aggregates required by the construction industry. During the past (1950's and $60^{\prime} 0 \mathrm{~s}$, there were commercial demands for quality quartz crystal required in the manufacture of medical and aerospace sensors (Moxon, 2004; Moxon \& Carpenter, 2009).

Of the intriguing topics that are receiving renewed attention nowadays, the study of the "triangle" biomineralization/demineralization/remineralization is among the most fascinating (Ehrlich et al., 2010).

Electric organs of the electric fish have constituted the choice model for studying the nervous cholinergic system (see: Changeux, 1981; 2010). This chapter shows the autofluorescent chalcedony in electric organs. Autofluorescent chalcedony was also documented in human brains from elderly patients (Prado Figueroa \& Sánchez Lihón, 2010).

There are many similarities in the occurrence of biosilicification in both systems. One of the major neurochemical features of Alzheimer's disease is the marked reduction of nicotinic acetylcholine receptor in relevant diseased brain regions such as the cerebral cortex and hippocampus (Oddo \& LaFerle, 2006). An important use of chalcedony crystals from electric organs is, maybe, in relation with the human medicine.

This paper has demonstrated, using different samples of electric organs, the way Laser Scanning Confocal Microscope with three dimensional (3D) images obtained by using a Leica Confocal Software can be employed to identify chalcedony and nanocrystalline silica polymorphs (quartz and moganite) in electric organs from marine fish.

This communication provides the first experimental evidence of biologically produced crystalline silica mineral phase (i.e., chalcedony) and its growth (crystallinity) in electric organs from living electric fish.

\section{Acknowledgment}

This research was partially supported by grants to María Prado Figueroa from Secretaría General de Ciencia y Técnica, Universidad Nacional del Sur (UNS), Bahía Blanca, Argentina. MPF is grateful to Dr. T. Moxon, 55 Common Lane, Auckley, Doncaster DN93HX, UK, for many interesting suggestions about chalcedony formation and isolation.

MPF is grateful to Prof. F.J. Barrantes, ex-Director of the Centro Científico Tecnológico Bahía Blanca, Argentina (CCT-BBca, CONICET - UNS) for his permanent interest in this study.

MPF appreciate Lic. E. Buzzi and Mr. M. Diestefano from the CCT-BBca, CONICET - UNS, for technical assistance. Finally, the author is very grateful to Lic. M. Salaberry, English Translator, for her excellent work. 


\section{References}

Amar-Costesec, A., Prado Figueroa, M., Beaufay, H., Nagelkerke, J.F., van Berkel, T.J.C., 1985. Analytical study of microsomes and isolated subcellular membranes from rat liver. IX. Nicotinamide adenine dinucleotide glycohydrolase: a plasma membrane enzyme prominently found in Kupffer cells. Journal of Cell Biology 100, 189-197.

Beaufay, H., Amar-Costesec, A., 1976. Cell fractionation techniques. In: Korn, E.D. (Ed.), Methods in Membrane Biology, vol. 6. Plenum Press, New York, London, pp. 1100.

Barrantes, F.J., Mieskes, G. \& Wallimann T., (1983). Creatine kinase activity in the Torpedo electrocyte and in the nonreceptor v-proteins from acetylcholine receptor-rich membranes. Proceeding National Academic of Sciences U.S.A, 80, 5440-5444.

Bustillo, M.A., 2002. Aparición y significado de la moganita en las rocas de la sílice: una revisión. Journal of Iberian Geology 28,157-166.

Carlisle, EM (1982) The nutritional essentiality of silicon. Nutritional Review. 40, 193-198.

Changeaux, J.P., (1981) The acetylcholine receptor: an "allosteric" membrane protein. Harvey Lecture 75, 85-254.

Changeaux, J.P., (2010) Allosteric receptors: from electric organ to cognition. Annu Rev Pharmacol Toxicol 50, 1-38.

Conrad, C.F., Yasuhara, H., Bandstra, J.Z., Icopini, G.A., Brantley, S.L., Heaney, P.J., (2007). Modeling the kinetics of silica nanocolloid formation and growth in aqueous solutions as a function of $\mathrm{pH}$ and ionic strength. Geochimic Cosmochimical. Acta 71, 531-542.

Deer, W.A., Howie, R.A., Zussman, J. (1966). An introduction to the rock-forming minerals. In: Longman Scientific and Technical, Longmans, Green and Co. Ltd., W. Clowes and Sons Ltd., London, 696 pp.

Erhlich, H. (2010). Chitin and collagen as universal and alternative templates in biomineralization, International Geology Review 52, 7, 661 - 699

Erhlich, H., Demadis, K.D. Pokrovsky, O.S. Koutsoukos, P.G. (2010). Modern views on desilicification: biosilica and abiotic silica dissolution in natural and artificial environments. Chemical Reviews 110, 4656-4689.

Fessard, A. (1958). Les organs éléctriques. In: P. Grassée (Ed.), Traité de Zoologie, vol. 13, 1143-1238. París, Masson.

Fernández López, S. (2000). Temas de tafonomía. Departamento de Paleontología. Fac. Cs. Geol. Universidad Complutense de Madrid. 167 pp. Madrid, Spain.

Fox, G.Q., Kriebel, M.E., Pappas, G.D. (1990). Morphological, physiological and biochemical observations on skate electric organ. Anatomy and Embryology 181, 305-315.

Hahn, Theo, (2002). International Tables for Crystallography, Vol. A: Space Group Symmetry, A. (5 $5^{\text {th }}$ ed.), Berlin, New York: Springer-Verlag.

Heaney, P.J. (1993). A proposed mechanism for the growth of chalcedony. Contributions of Mineralogical Petrology 114, 66-74.

Heaney, P.J., Post, J.E., (1992). The widespread distribution of a novel silica polymorph in microcrystalline quartz varieties. Science 255, 441-443.

Heaney, P.J., Veblen, D.R., Post, J.E., (1994). Structural disparities between chalcedony and macrocrystalline quartz. American Mineralogist 79, 452-460. 
Heaney, P.J., Mc Keown, D.A., Post, J.E., (2007). Anomalous behavior at the I2/a to Imab phase transition in SiO2-moganite: an analysis using hard-mode Raman spectroscopy. American Mineralogist 92, 631-639.

Henkel, G. (1989). The Henkel glossary of fluorescent minerals. Journal of the Fluorescent Mineral Society 15, 1 - 91.

Jacob, B.A., Mc Eachran J.D., Lyons P.L. (1994) Electric organ in skate: variation and phylogenetic significance (Chondrichthyes: Rajoidei). J. Morphology 221, 45-63.

Krumbein, W.C., Garrels, R.M., (1952). The origin and classification of chemical sediments in terms of $\mathrm{pH}$ and oxidation-reduction potentials. Journal of Geology 60, 1-33.

Moore, D.M., \& Reynolds, R.C., (1997). X-ray Diffraction and the Identification and Analysis of Clay Minerals. In Oxford University Press, New York, 378 pp.

Moxon, T. (2004) Moganite and water content as a function of age in agate. European Journal of Mineralogy 16, 269-278.

Moxon, T. \& Carpenter, M.A. (2009). Crystallite growth kinetics in nanocrystalline quartz (agate and chalcedony). Mineralogical Magazine, 73(4), 551-568.

Nash, D.J., Hopkinson, L. (2004) A reconnaissance laser Raman and Fourier transform infrared survey of silcretes from the Kalahari desert, Botswana. Earth Surf. Process. Landforms 29, 1541-1558.

Oddo, S. \& LaFerle, F.M. (2006). The role of nicotinic acetylcholine receptors in Alzeimer's disease. Journal of Physiology (Paris) 99, 172-179.

Prado Figueroa, M. (2005). Distribución cuantitativa del malondialdehido entre las fracciones subcelulares obtenidas por centrifugación diferencial de órganos eléctricos de peces de la familia Rajidae y topografía del nAChR. III Jornadas de Bioquímica y Biología Molecular de Lípidos y Lipoproteínas. Bahía Blanca, Argentina, p. 101.

Prado Figueroa, M., Santiago, J. (2004). Intracellular localization of a long alkyl chain tetraphenylporphyrin and chloride channel activation in Psammobatis extenta electrocytes. Photochem. Photobiol. Sci. 3, 33-35.

Prado Figueroa, M. \& Sánchez Lihón, J (2010). Autofluorescent chalcedony in human brains from elderly patients. Biotechnic and Histochemistry 85, 171-176.

Prado Figueroa, M., Vidal, A. \& Barrantes, F. J. (1995). Ultrastructure of Psammobatis extent (Rajidae) electrocytes and cytochemical localization of acetylcholinesterase, acetylcholine receptor and F-actin. BIOCELL 19, 113-123.

Prado Figueroa, M., Barrera, F., Cesaretti, N.N., (2008). Chalcedony (a crystalline variety of silica): biogenic origin in electric organs from living Psammobatis extenta (family Rajidae). Micron 39, 1027-1035.

Rasmuson, A.C. (2009). Introduction to crystallization of fine chemicals and pharmaceuticals. In: Molecules: nucleation, aggregation and crystallization. Ed. J. Sedzik \& P. Riccio. World Scientific Publishing Co. Pte. Ltd., Singapore; New Jersey, USA; London, UK, pp. 145-172.

Schroder, H.C., Wang X., Tremel, W., Ushijima, H., Muller W.E. (2008). Biofabrication of biosilica-glass by living organisms. Natural Product Reports 25, 455-474.

Schwarz, K. (1973). A bound form of silicon in glycosaminoglycans and polyuronides. Proceeding National Academic of Science USA, 70, 1608-1612. 
Whittaker, V.P. (1977). The electromotor system of Torpedo as a model cholinergic system. Naturwissenschaften 64, 606-611. 


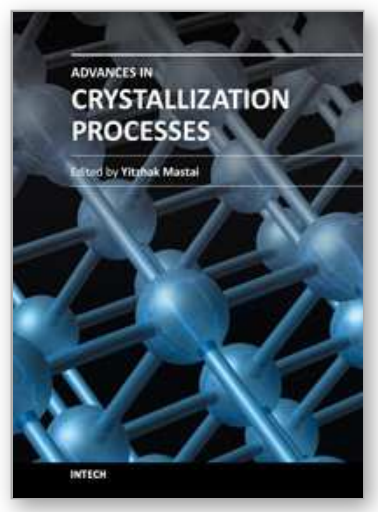

\section{Advances in Crystallization Processes}

Edited by Dr. Yitzhak Mastai

ISBN 978-953-51-0581-7

Hard cover, 648 pages

Publisher InTech

Published online 27, April, 2012

Published in print edition April, 2012

Crystallization is used at some stage in nearly all process industries as a method of production, purification or recovery of solid materials. In recent years, a number of new applications have also come to rely on crystallization processes such as the crystallization of nano and amorphous materials. The articles for this book have been contributed by the most respected researchers in this area and cover the frontier areas of research and developments in crystallization processes. Divided into five parts this book provides the latest research developments in many aspects of crystallization including: chiral crystallization, crystallization of nanomaterials and the crystallization of amorphous and glassy materials. This book is of interest to both fundamental research and also to practicing scientists and will prove invaluable to all chemical engineers and industrial chemists in the process industries as well as crystallization workers and students in industry and academia.

\section{How to reference}

In order to correctly reference this scholarly work, feel free to copy and paste the following:

María Prado Figueroa (2012). The Growth of Chalcedony (Nanocrystalline Silica) in Electric Organs from Living Marine Fish, Advances in Crystallization Processes, Dr. Yitzhak Mastai (Ed.), ISBN: 978-953-51-0581-7, InTech, Available from: http://www.intechopen.com/books/advances-in-crystallization-processes/the-growth-ofchalcedony-nanocrystalline-silica-in-living-marine-fish

\section{INTECH}

open science | open minds

\section{InTech Europe}

University Campus STeP Ri

Slavka Krautzeka 83/A

51000 Rijeka, Croatia

Phone: +385 (51) 770447

Fax: +385 (51) 686166

www.intechopen.com

\section{InTech China}

Unit 405, Office Block, Hotel Equatorial Shanghai

No.65, Yan An Road (West), Shanghai, 200040, China 中国上海市延安西路65号上海国际贵都大饭店办公楼 405 单元

Phone: +86-21-62489820

Fax: $+86-21-62489821$ 
(C) 2012 The Author(s). Licensee IntechOpen. This is an open access article distributed under the terms of the Creative Commons Attribution 3.0 License, which permits unrestricted use, distribution, and reproduction in any medium, provided the original work is properly cited. 